\title{
ASSOCIATION OF PERIPHYTIC DIATOM SPECIES OF ARTIFICIAL SUBSTRATE IN LOTIC ENVIRONMENTS IN THE ARROIO SAMPAIO BASIN, RS, BRAZIL: RELATIONSHIPS WITH ABIOTIC VARIABLES
}

\author{
OLIVEIRA, M. A., ${ }^{1}$ TORGAN, L. C., ${ }^{1}$ LOBO, E. A. ${ }^{2}$ and SCHARZBOLD, A. ${ }^{3}$ \\ ${ }^{1}$ Museu de Ciências Naturais da Fundação Zoobotânica do Rio Grande do Sul, C.P. 1188, CEP 90690-000, \\ Porto Alegre, RS, Brazil \\ ${ }^{2}$ Departamento de Biologia, Universidade de Santa Cruz do Sul, C.P. 188, CEP 96815-900, \\ Santa Cruz do Sul, RS, Brazil \\ ${ }^{3}$ Curso de Pós-graduação em Ecologia, Universidade Federal do Rio Grande do Sul, Av. Bento Gonçalves, 9500, \\ Prédio 43411, CEP 91540-000, Porto Alegre, RS, Brazil \\ Correspondence to: Lezilda Carvalho Torgan, Museu de Ciências Naturais da Fundação Zoobotânica do \\ Rio Grande do Sul, C.P. 1188, CEP 90690-000, Porto Alegre, RS, Brazil, e-mail: torgan@ cpovo.net \\ Received January 18, 1999 - Accepted June 23, 2000 - Distributed November 30, 2001
}

(With 45 figures)

\begin{abstract}
Associations of diatom species were identified, in the Arroio Sampaio Basin, Rio Grande do Sul, Brazil, based on monthly samplings over a year along Arroio Sampaio and its main tributaries, using polyamide thread as an artificial substrate. The species groupings showed four different environments: medium-lower course of Arroio Sampaio; and lower course of Arroio Teresinha; upper course of Arroio Sampaio; and lower course of Arroio Duvidosa. Among the physical and chemical variables measured, water pollution, particularly organic contamination and eutrophication, measured from $\mathrm{BOD}_{5}$ and total phosphate concentration, respectively, appeared to be one of the most important environmental factors determining the composition and structure of species associations in the area studied.
\end{abstract}

Key words: periphytic diatoms, species association, lotic system.

\section{RESUMO}

Associação de espécies de diatomáceas perifíticas de substrato artificial, em ambientes lóticos da Bacia do Arroio Sampaio, RS, Brasil: relação com variáveis abióticas

Foram identificadas associações de espécies de diatomáceas na Bacia do Arroio Sampaio, Rio Grande do Sul, Brasil. O resultado baseou-se em amostragens mensais, no período de um ano, ao longo do Arroio Sampaio e seus afluentes, utilizando-se fio de poliamida como substrato artificial. Os agrupamentos de espécies revelaram quatro ambientes distintos: curso médio-inferior do Arroio Sampaio; curso inferior do Arroio Teresinha; curso superior do Arroio Sampaio; e curso inferior do Arroio Duvidosa. Dentre as variáveis físicas e químicas medidas, a poluição da água, particularmente, a contaminação orgânica e a eutrofização, determinadas a partir da $\mathrm{DBO}_{5}$, e a concentração de fosfato total, respectivamente, destacaram-se como os fatores ambientais mais importantes na determinação da composição e da estrutura das associações de espécies na área de estudo.

Palavras-chave: diatomáceas perifíticas, associação de espécies, sistema lótico. 


\section{INTRODUCTION}

Studies on the periphytic community are scarce and recent in the state of Rio Grande do Sul. They were done both on natural and artificial substrate. For lentic systems, community structure and dynamics in coastal lagoons were examined (Tedesco, 1995; Fermino-Paganoto, 1997). In lotic systems, studies were carried out on time of colonization, distribution in the substrate, and use of the diatom community as a water quality indicator, in rivers of the Jacuí Basin (Lobo \& BuselatoToniolii, 1985; Lobo et al., 1990, 1995, 1996; Lobo \& Bender, 1998; Lobo \& Ben da Costa, 1997, and others). This basin covers $50 \%$ of the state surface, and is formed of a broad hydrographic network which includes the Taquari River into which Arroio Sampaio flows.

Arroio Sampaio's waters drain into a region with strong basalt flow relief energy. It is located between co-ordinates $29^{\circ} 21^{\prime}-29^{\circ} 33^{\prime} \mathrm{S}$ and $51^{\circ} 58^{\prime}$ $52^{\circ} 22^{\prime} \mathrm{W}$, covering an area of $253.2 \mathrm{~km}^{2}$. The main channel is formed at the top of the mountains of Serra Geral, and extends to the Central Depression, along $64.4 \mathrm{~km}$.

The study of the periphytic community on an artificial substrate in Arroio Sampaio and its tributaries, performed by Oliveira (1996), showed that the diatom groups were most representative of the community in this system as to wealth and abundance of species, rendering invaluable a more detailed investigation of this group. Therefore, the main purpose of this study was to describe the diatom species associations existing throughout the system and to look at their relationships with abiotic variables.

\section{MATERIAL AND METHODS}

Monthly samplings of physical and chemical variables and of periphyton were performed during the period from July 1994 to June 1995, at four stations on Arroio Sampaio (station 1, lower reach; stations 3 and 5 , middle reach; and station 6 , higher reach) and three in the lower course of the tributaries (station 2, Arroio Sampainho; station 4, Arroio Teresinha; station 7, Arroio Duvidosa), represented in Fig. 1.

Variables of temperature, conductivity, $\mathrm{pH}$, turbidity, quantity of total solids, dissolved oxygen, biochemical oxygen demand $\left(\mathrm{BOD}_{5}\right)$, nitrates, nitrites, and phosphates, were measured and analyzed according to APHA (1992).

Water quality evaluation, in terms of organic pollution, was based on $\mathrm{BOD}_{5}$, according to the chemical classification of water quality proposed by Hamm (1969) and for total phosphate the CONAMA water classification was used (CONAMA, 1986), as established in resolution $\mathrm{Nr} 20$.

In order to obtain periphytic material, $2 \mathrm{~mm}$ diameter polyamide threads were exposed as substrate, because they were easier to remove and the colonized surface was easier to calculate. The periphyton was removed from the substrate and preserved in the laboratory with F.A.A. solution (Gough \& Woelkerling, 1976). Analysis of material was performed in sedimentation chambers with volumes of 2.2 and $25 \mathrm{ml}$, using an inverted microscope. The Utermöhl method (1958) was utilized for quantification, applying the formula of Wetzel \& Likens (1990) modified by Schwarzbold (1992). The results were expressed in ind./ $\mathrm{cm}^{2}$. To identify the diatoms on a specific level, the material was prepared according to the quick oxidation method of Müller-Melchers \& Ferrando (1956). The classification system of Round et al. (1990) was adopted for taxonomic classification of the diatoms. Permanent slides were mounted with Naphrax, and are preserved in the Prof. Dr. Alarich R. H. Schultz Herbarium at the Museu de Ciências Naturais, Fundação Zoobotânica do Rio Grande do Sul, registered under numbers 4892 to 4933.

Beginning with the data matrix generated by quantitative analysis of the diatom community, sampling units, and variables (species) were classified by analyzing groupings. In order to reduce the effect of data discrepancy, a logarithmic transformation was applied (Digby \& Kempton, 1987). The similarity measure used was the Euclidian distance squared, and minimum variance was chosen as a connection technique (Pielou, 1984). Concentration analysis was also performed in order to find out which groups of species associations have the greatest affinity with the sampling unit groups. The Syncsa Program was used (Pillar, 1995b).

In order to process the information, the nonparametric statistical Mann-Whitney U-test (Siegel, 1956) was used to compare the distributions of populations of physical and chemical variables measured in different groups of sampling units. 


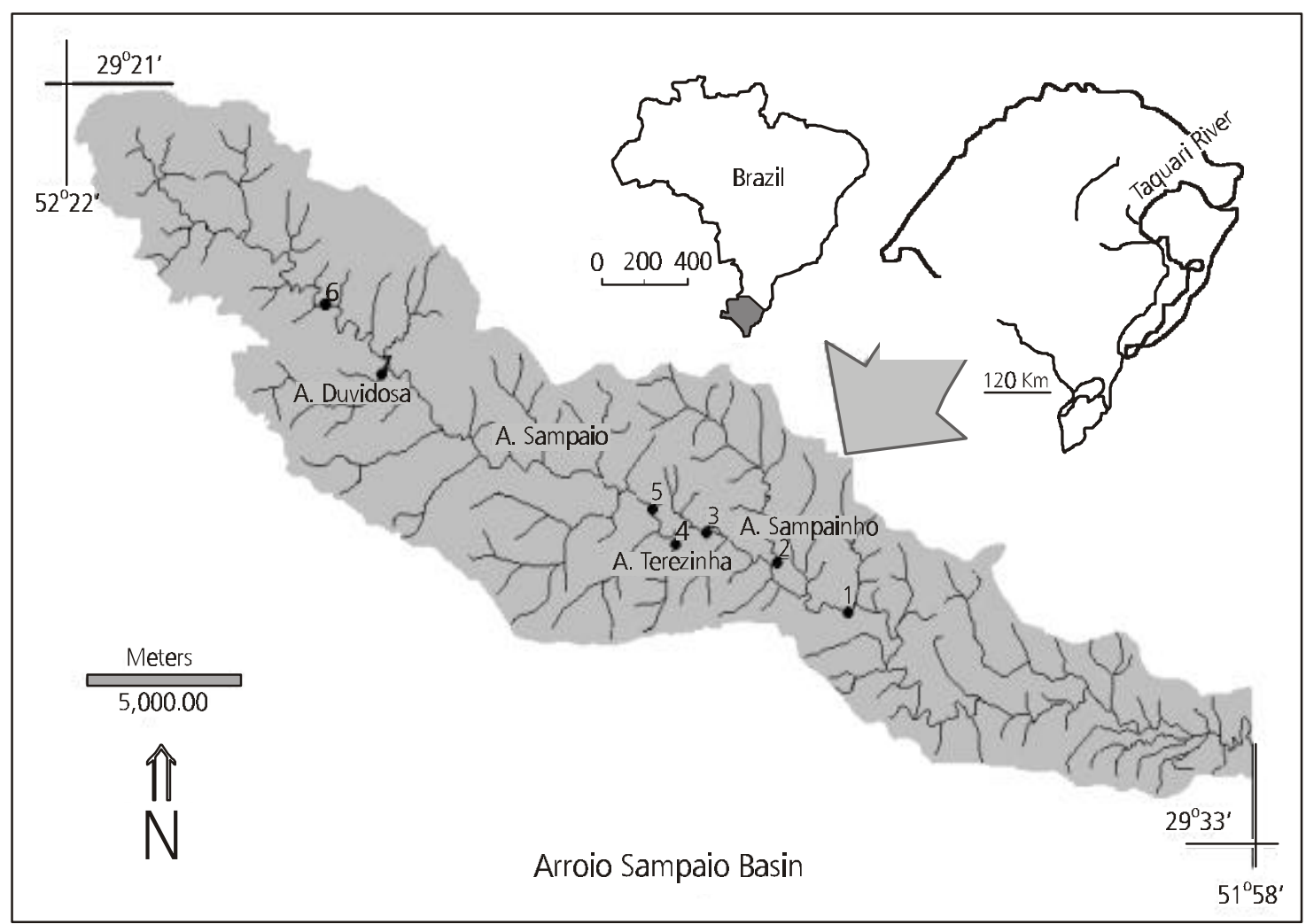

Fig. 1 - Location of the sampling stations in Arroio Sampaio Basin.

Similarly, a hypothesis test was used, via randomization, by means of the Multiv Program (Pillar, 1995a). In all cases, significance levels of $5 \%$ were applied.

\section{RESULTS AND DISCUSSION}

The periphytic diatom community of the Arroio Sampaio Basin was constituted of 45 taxa, distributed among the families Achnanthaceae, Amphipleuraceae, Bacillariaceae, Cocconeidaceae, Cymbellaceae, Diadesmidaceae, Eunotiaceae, Fragilariaceae, Gomphonemataceae, Melosiraceae, Naviculaceae, Pinulariaceae, Pleurosigmataceae, Sellaphoraceae, Stephanodiscaceae, and Surirellaceae.

The results of the grouping analysis of the sampling units, based on the diatom species, showed a variation of the community according to sampling stations (Fig. 2). Four main groups were identified, labeled numbers 1, 2, 3, and 4. Group 1 was constituted by sampling units from all sam- pling stations throughout the sampling period, with a strong dominance of stations 1,3 , and 5 , referring to the middle/lower reach of Arroio Sampaio, beyond station 2 located in Arroio Sampainho, whose confluence with Arroio Sampaio lies in the middle/lower reach of the latter. Group 2 was constituted by sampling units of station 4 (Arroio Teresinha) in the spring, fall, and winter months. In group 3, most sampling units of the upper reach of Arroio Sampaio (station 6) were found, as well as sampling units from stations 2 and 7 (Arroios Sampainho and Duvidosa). Group 4 was formed by sampling units from station 7 (Arroio Duvidosa) and also by summer samplings from station 4 . No time trend was observed for the grouping in sampling units.

Four species groups were identified, called $\mathrm{a}, \mathrm{b}, \mathrm{c}$, and d, based on the result of the analysis of a grouping of diatom species as a function of their densities (Fig. 3). The composition of the species of the different groups was determined by the following taxa: 


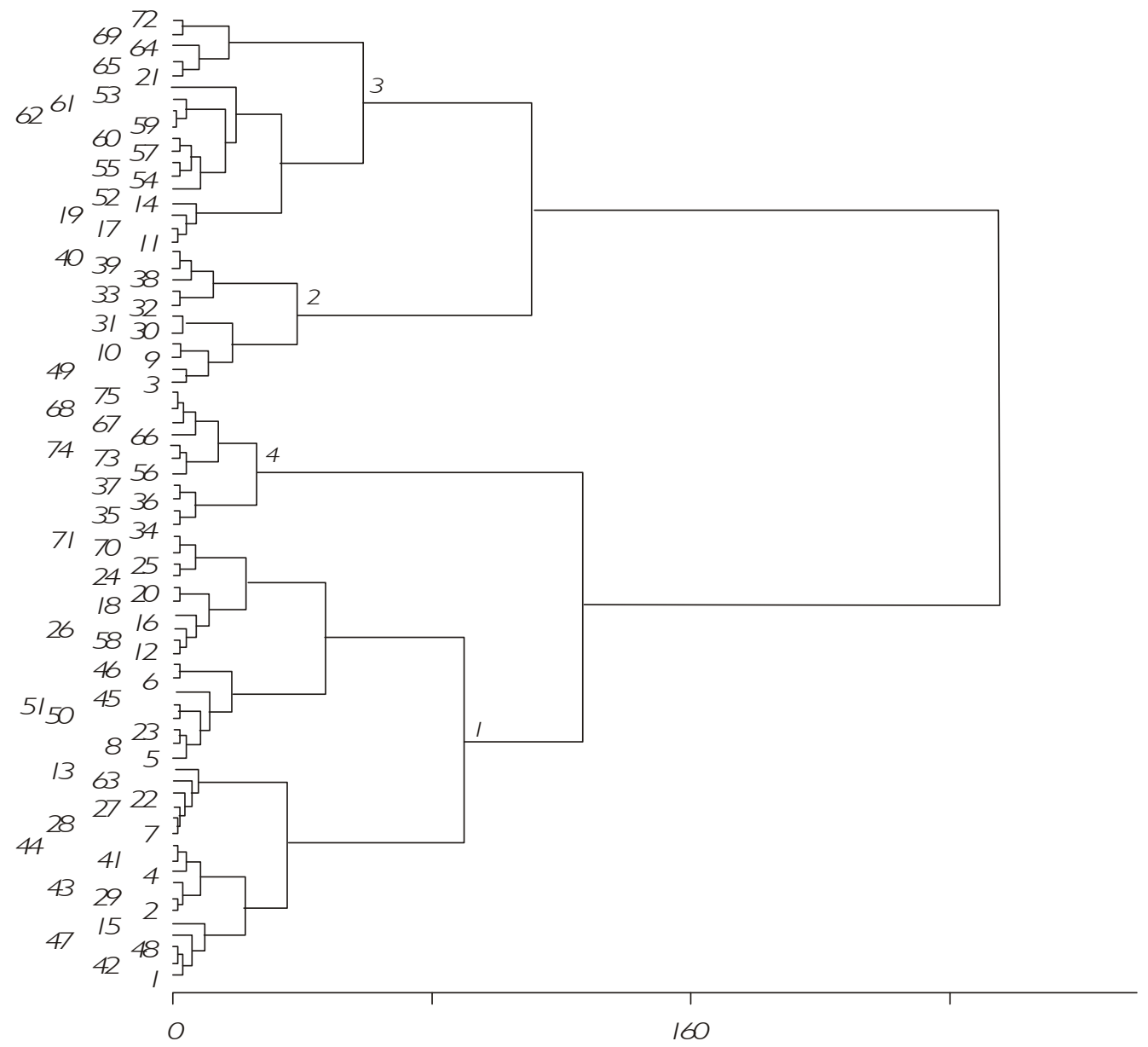

Fig. 2 - Analysis of the sampling unit groupings as a function of the densities of periphytic diatom species.

\section{Group a:}

Achnanthes exigua Grunow var. constricta (Torka) Hustedt (Acex) - Fig. 4

Melosira varians Agardh (Meva) - Fig. 5

Cymbella tumida (Brébisson) Van Heurck (Cytu) - Fig. 6

Fig. 7

Amphipleura lindheimeri Grunow (Amli) Fig. 8

Planothidium lanceolatum Round (Plla) -

Gomphonema pumilum (Grunow) Reichardt

\& Lange-Bertalot (Gopu) - Fig. 9

Navicula cryptotenella Lange-Bertalot (Nact) - Fig. 10

Sellaphora pupula (Kützing) Mereschkowsky (Napu) - Fig. 11
Gyrosigma scalproides (Rabhenhorst) Cleve (Gysc) - Fig. 12

Navicula viridula (Kützing) Ehrenberg var. rostellata (Kützing) Cleve (Naro) - Fig. 13

Gomphonema pseudoaugur Lange-Bertalot (Gops) - Fig. 14

\section{Group b:}

Achnanthes inflata (Kützing) Grunow in Cleve \& Grunow (Acin) - Fig. 15

Eunotia incisa Gregory (Euin) - Fig.16

Eunotia praerupta Ehrenberg (Eupr) - Fig. 17

Frustulia vulgaris (Thwaites) De Toni (Frvu) - Fig. 18

Hantzschia amphioxys (Ehrenberg) Grunow in Cleve \& Grunow (Haan) - Fig. 19 


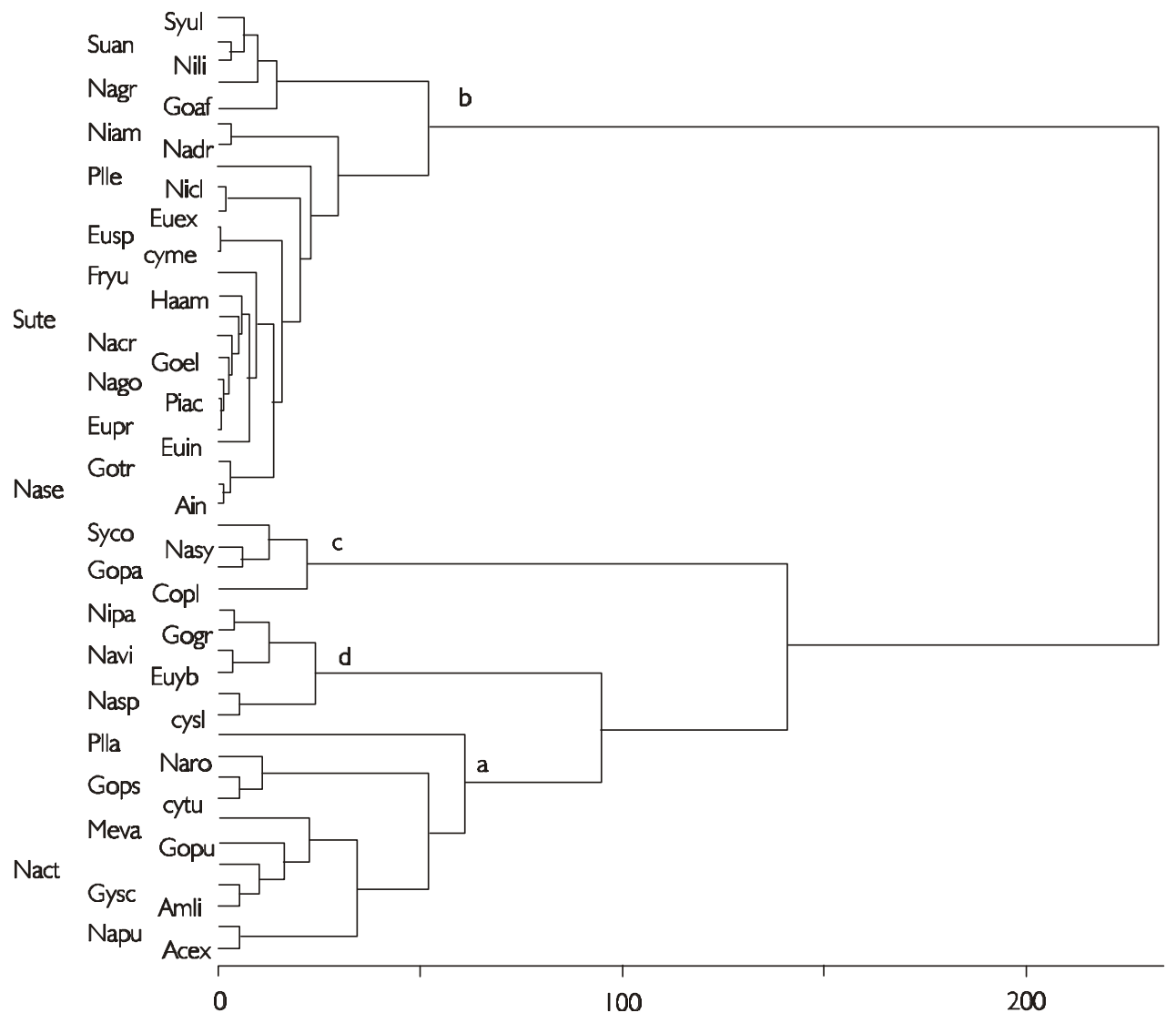

Fig. 3 - Analysis of groupings of diatom species as a function of their densities.

Fig. 20

$$
\text { Cyclotella meneghiniana Kützing (Cyme) - }
$$
21

Gomphonema affine Kützing (Goaf) - Fig.

Gomphonema truncatum Ehrenberg (Gotr) Fig. 22

Nitzschia linearis (Agardh) W. Smith (Nili) Fig. 23

Luticola goeppertiana (Bleisch in Rabenhorst) D. G. Mann (Nago) - Fig. 24

Navicula gregaria Donkin (Nagr) - Fig. 25 Navicula cryptocephala Kützing (Nacr) Fig. 26

Nitzschia clausii Hantzsch (Nicl) - Fig. 27 Navicula drouetiana Patrick (Nadr) - Fig. 28

Nitzschia amphibia Grunow (Niam) - Fig. 29 Surirella angusta Kützing (Suan) - Fig. 30
Surirella tenera Gregory (Sute) - Fig. 31 Synedra ulna (Nitzsche) Ehrenberg (Syul) Fig. 32

Eunotia exigua (Brébisson ex Kützing) Rabenhorst (Euex)

Eunotia sp. (Eusp)

Gomphonema ellipticum Patrick (Goel)

Pinnularia acrosphaeria W. Smith (Piac)

Pleurosira laevis (Ehrenberg) Compère (Plle)

Sellaphora seminulum (Grunow) D. G. Mann (Nase)

Group c:

Cocconeis placentula Ehrenberg var. euglypta (Ehrenberg) Grunow (Copl) - Figs. 3334

Synedra ulna (Nitzsche) Ehrenberg var. contracta Östrup (Syco) - Fig. 35 

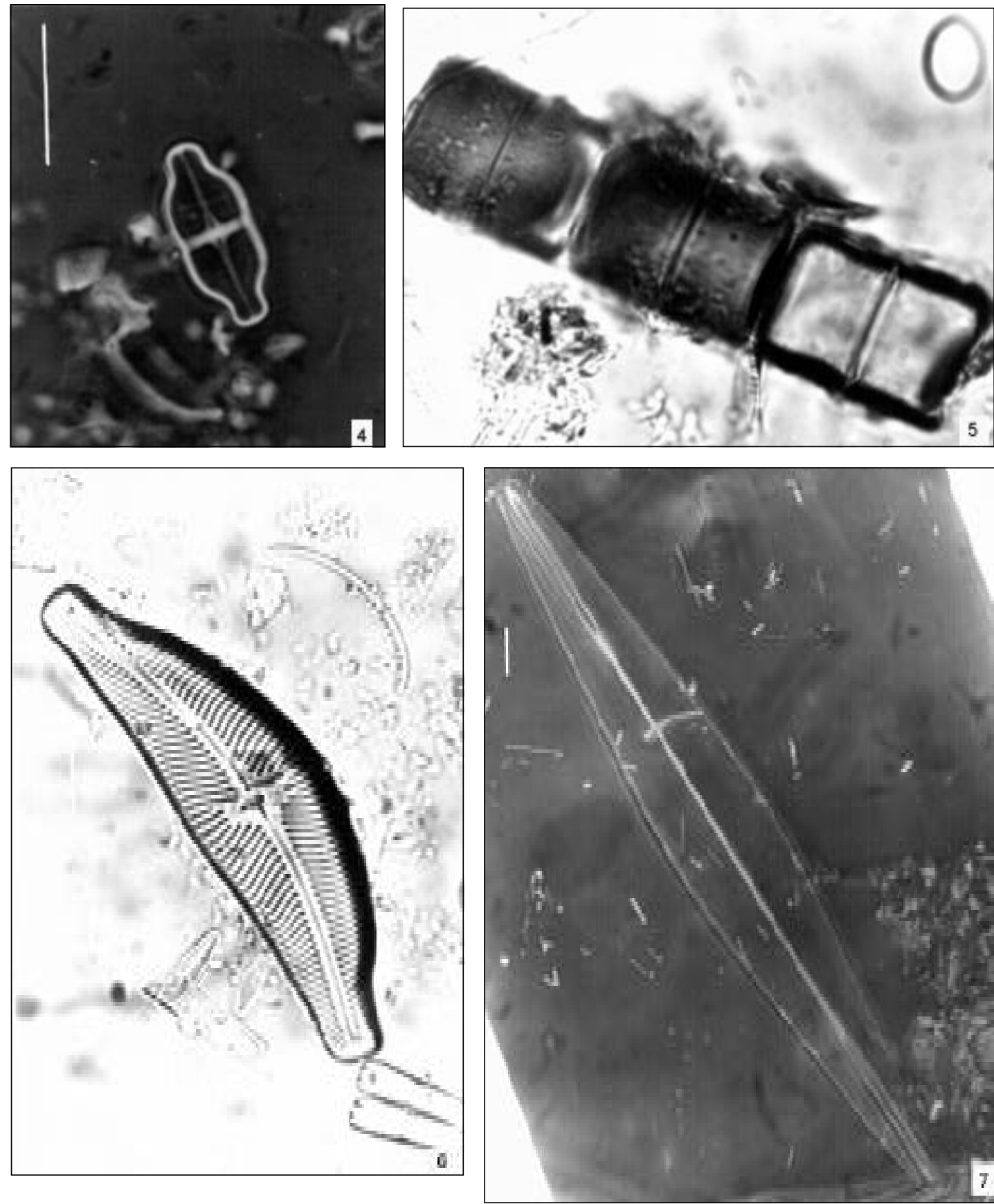

Figs. 4-7 - Association of representative species in the upper reach of Arroio Sampaio. 4 - Achnanthes exigua var. constricta. 5 - Melosira varians. 6 - Cymbella tumida. 7 - Amphipleura lindheimeri.

Gomphonema parvulum (Kützing) Kützing (Gopa) - Fig. 36

Navicula symmetrica Patrick (Nasy) - Fig. 37

\section{Group d:}

Eunotia yberai Frenguelli (Euyb)- Fig. 38 Gomphonema gracile Ehrenberg (Gogr) Fig. 39 

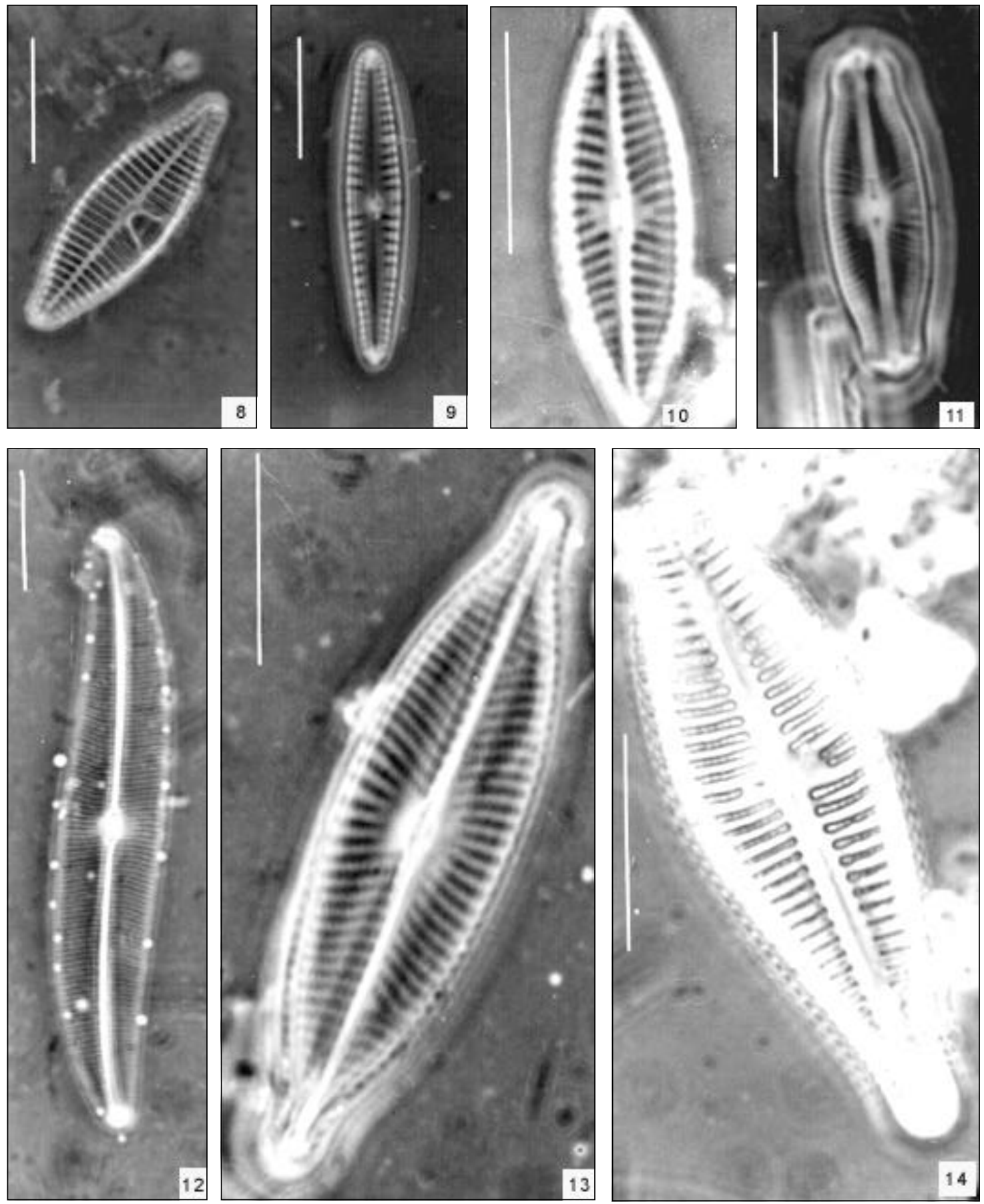

Figs. 8-14 - Association of representative species in the upper reach of Arroio Sampaio. 8 - Planothidium lanceolatum. 9 - Gomphonema pumilum. 10 - Navicula cryptotenella. 11 - Sellaphora pupula. 12 - Gyrosigma scalproides. 13 Navicula viridula var. rostellata. 14 - Gomphonema pseudoaugur. 

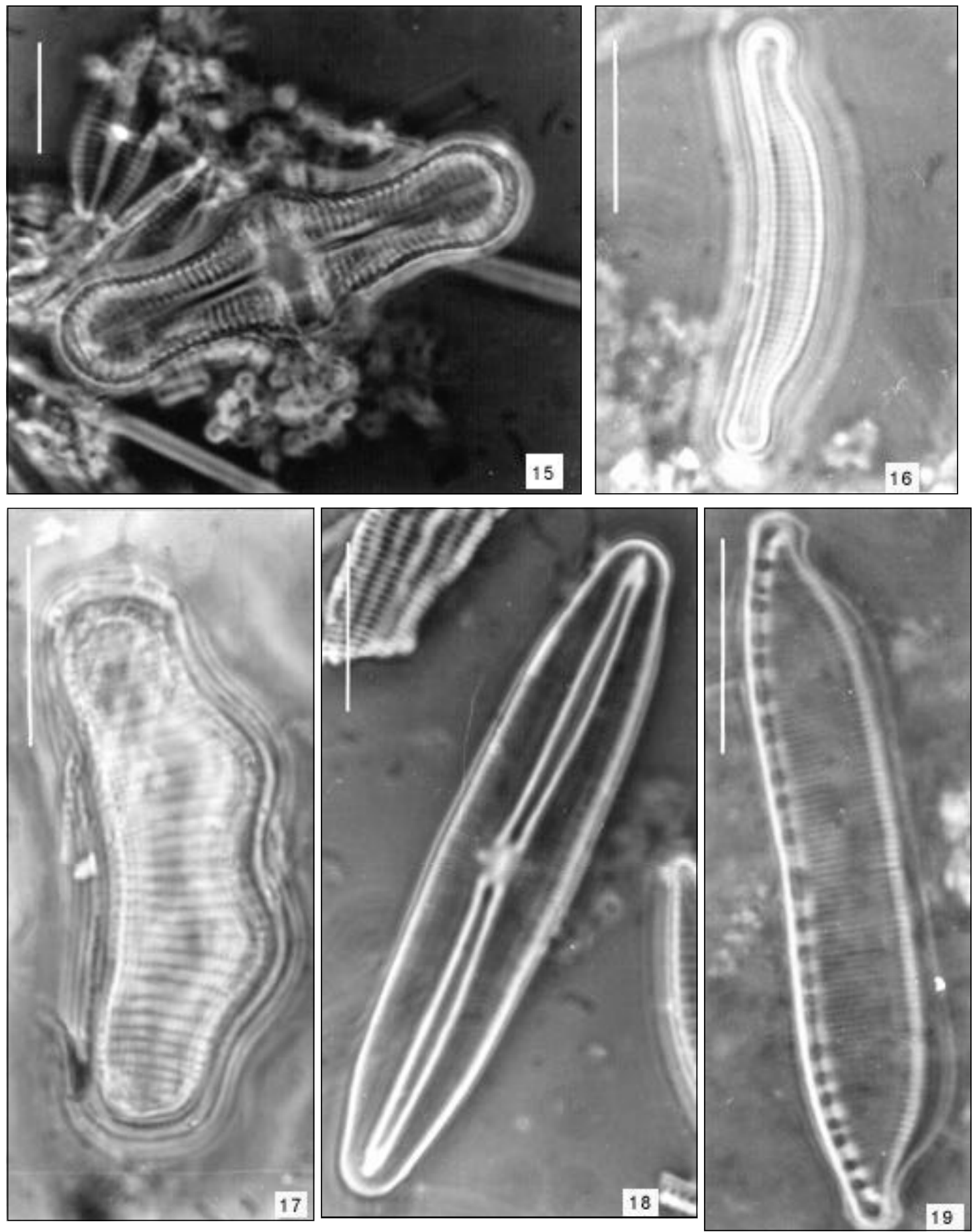

Figs. 15-19 - Association of representative species in the upper reach of Arroio Sampaio. 15 - Achnanthes inflata. 16 Eunotia incisa. 17 - Eunotia praerupta. 18 - Frustulia vulgaris. 19 - Hantzschia amphioxys. 

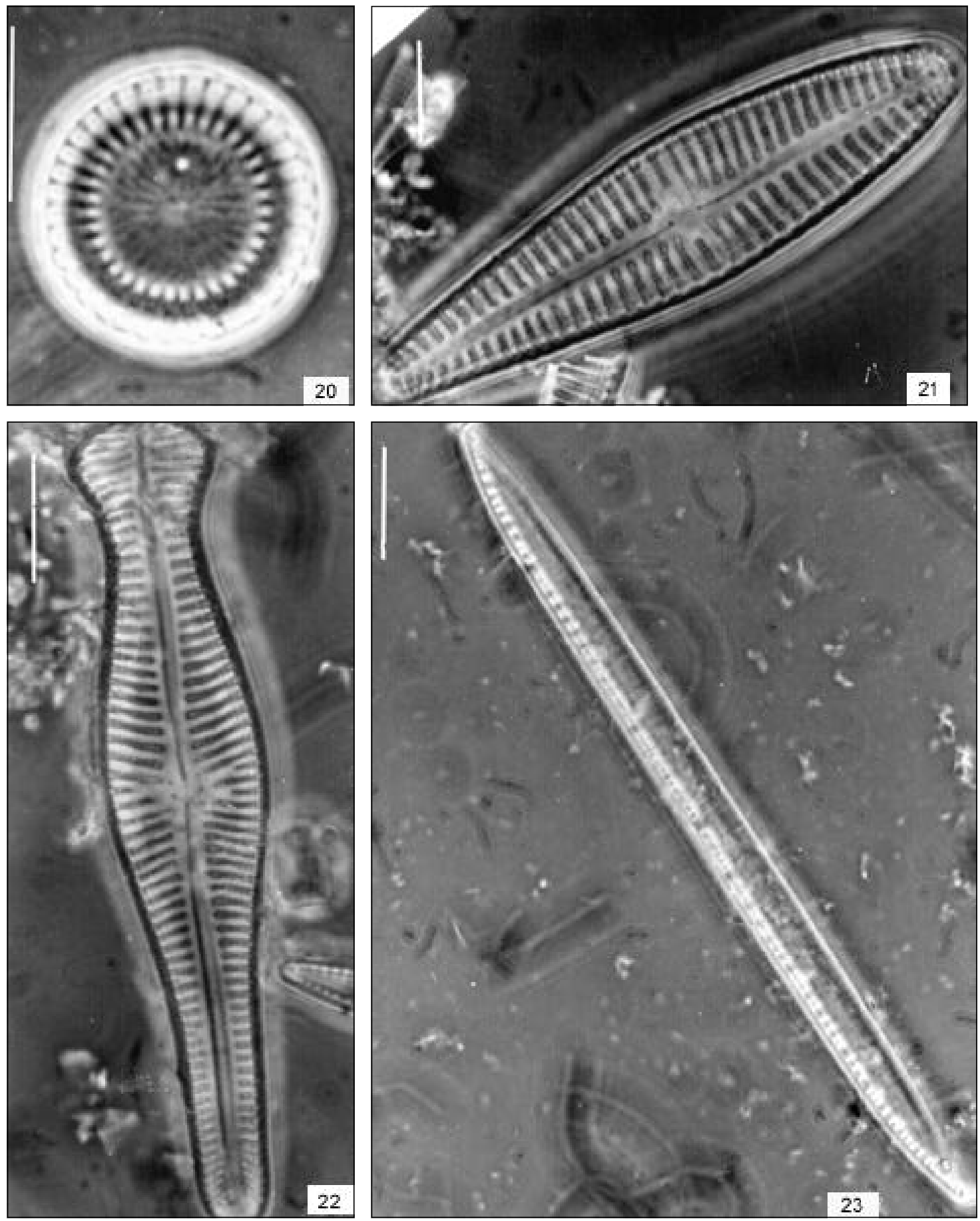

Figs. 20-23 - Association of representative species in the upper reach of Arroio Sampaio. 20 - Cyclotella meneghiniana. 21 - Gomphonema affine. 22 - Gomphonema truncatum. 23 - Nitzschia linearis. 

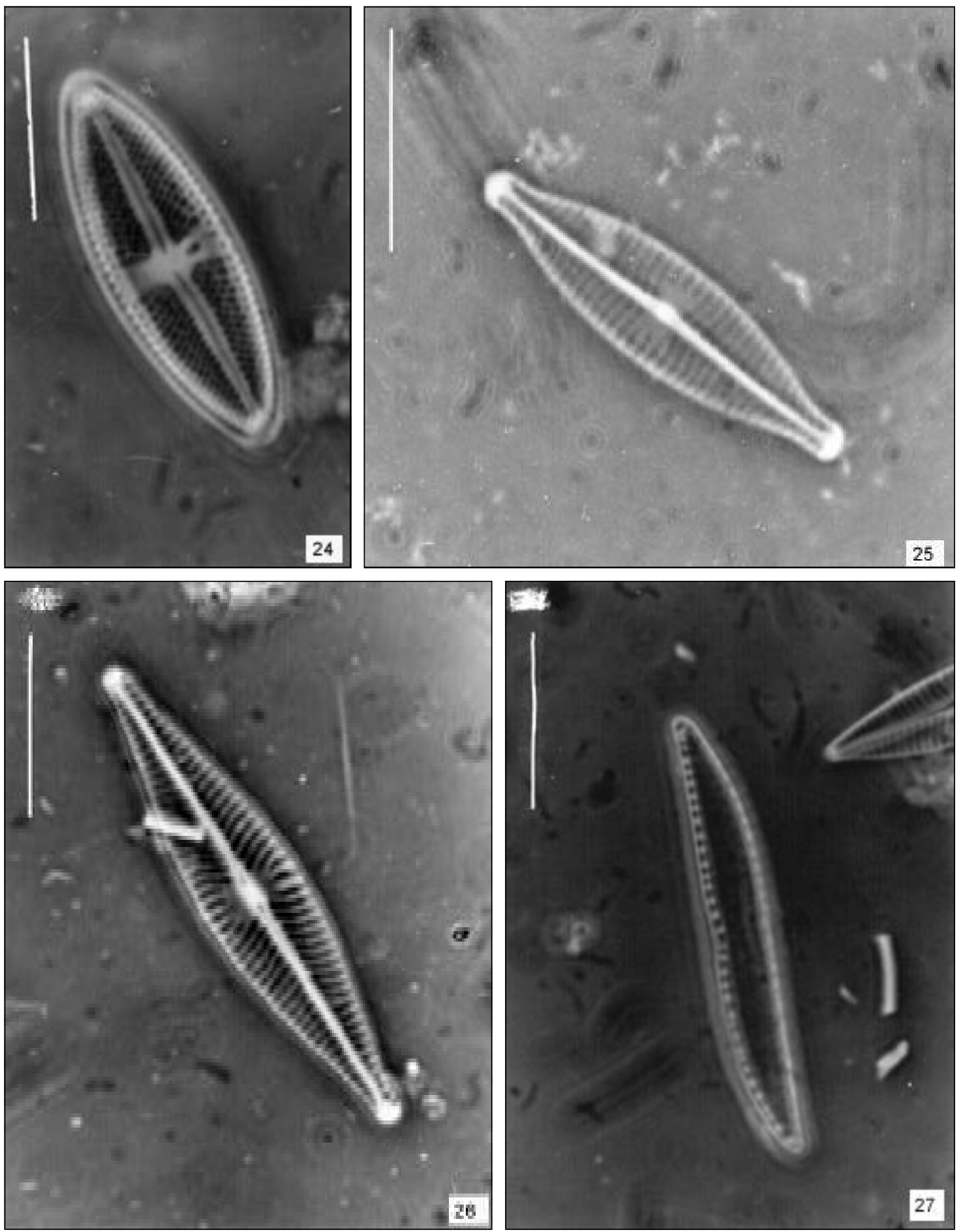

Figs. 24-27 - Association of representative species in the upper reach of Arroio Sampaio. 24 - Luticola goeppertiana. 25 - Navicula gregaria. 26 - Navicula cryptocephala. 27 - Nitzschia clausii. 

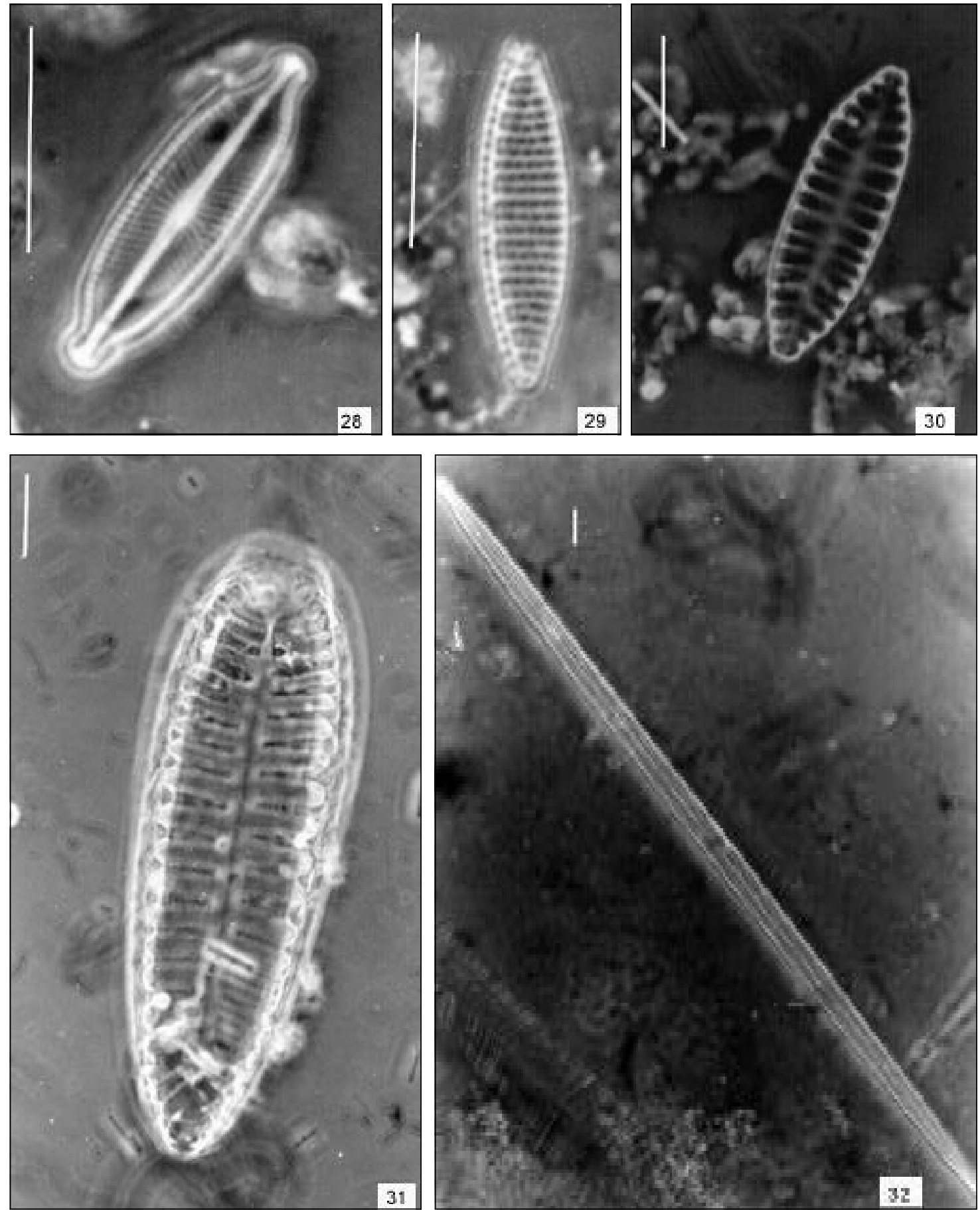

Figs. 28-32 - Association of representative species in the upper reach of Arroio Sampaio. 28 - Navicula drouetiana. 29 Nitzschia amphibia. $\mathbf{3 0}$ - Surirella angusta. 31 - Surirella tenera. 32 - Synedra ulna. 

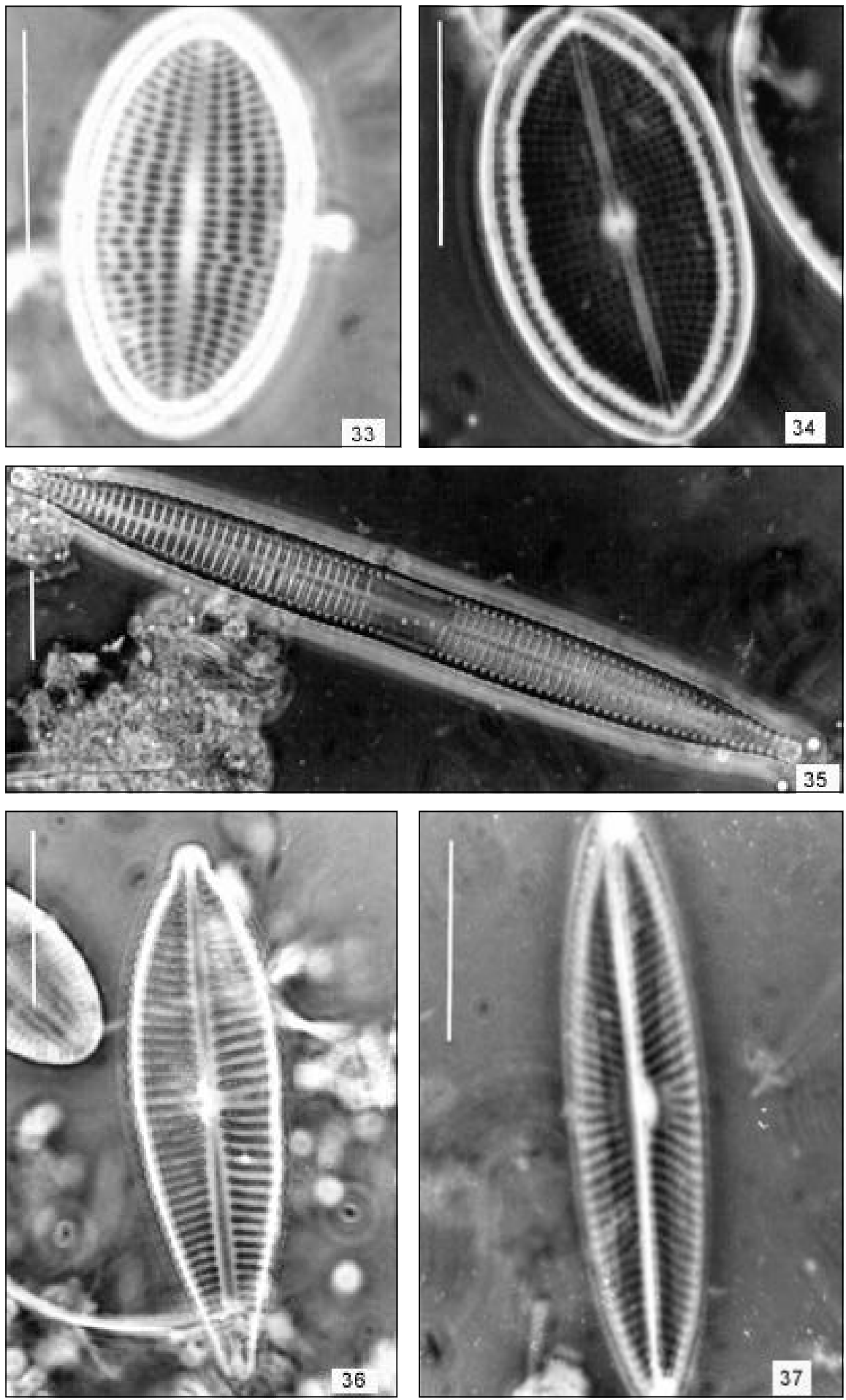

Figs. 33-37 - Association of representative species in the lower reach of Arroio Duvidosa. 33 - Cocconeis placentula var. euglypta, valve without raphe. 34 - Cocconeis placentula var. euglypta, valve with raphe. 35 - Synedra ulna var. contracta. $\mathbf{3 6}$ - Gomphonema parvulum. $\mathbf{3 7}$ - Navicula symmetrica. 

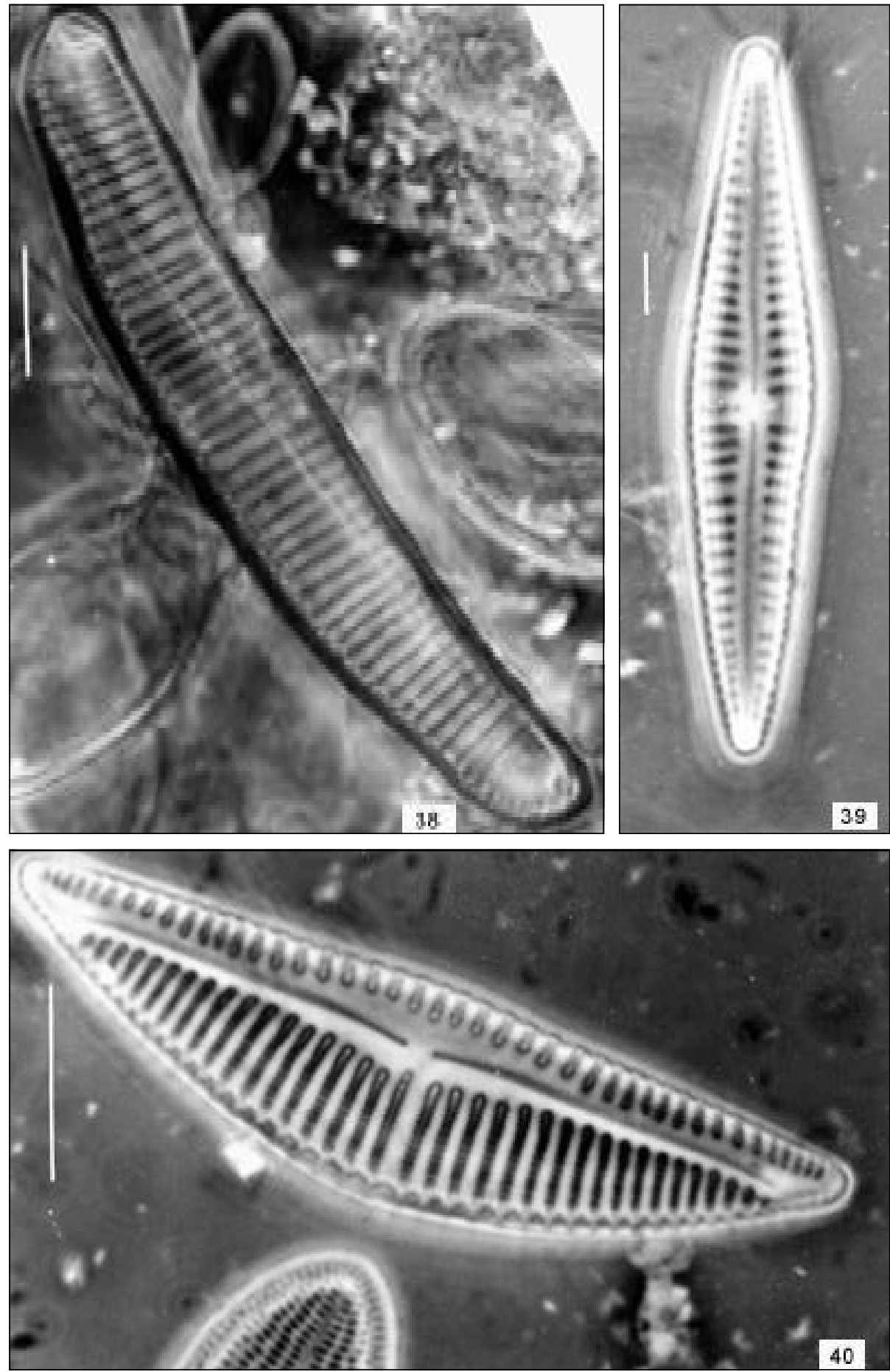

Figs. 38-40 - Association of representative species in the lower course of Arroio Teresinha. 38 - Eunotia yberai. 39 Gomphonema gracile. 40 - Encyonema mesianum. 
Encyonema mesianum (Cholnoky) D. G. Mann (Cysl) - Fig. 40

Navicula viridula (Kützing) Ehrenberg (Navi) Fig. 41

Nitzschia palea (Kützing ) W. Smith (Nipa) Fig. 42

Navicula aikenensis Patrick (Nasp)

(figures 4 to 42 or alternating between the above mentioned groups.)

The relationship of species associations with the sampling unit groups could be verified by means of the dispersion diagram generated by concentration analysis (Fig. 43). Axis I accounted for $92.7 \%$ of the variation of data in the original contingency table, while axis II represented 7.0\%.

Thus, as regards axis I, it was found that species association group $\mathrm{c}$ was characteristic of the middle/lower reach of Arroio Sampaio (group 1) and of Arroios Duvidosa and Teresinha during the summer months (group 4). This group was formed by Cocconeis placentula var. euglypta, Gomphonema parvulum, Navicula symmetrica and Synedra ulna var. contracta, which were more frequent and abundant at all sampling stations, except the upper reach of Arroio Sampaio

Species association group $\mathrm{d}$ characterized mainly the periphyton of Arroio Teresinha, since it was related to group 2 of the sampling units. This group was constituted by Encyonema mesianum and Navicula aikenensis, found in large numbers, and by Eunotia yberai and Navicula viridula which were different because of their exclusiveness.

As for axis II, species association groups a and $\mathrm{b}$ characterized group 3 of the sampling units, and those formed by $78 \%$ of the species recorded in the study, showing a greater wealth of species (11 and 24 species, respectively), occurred in the upper reach of Arroio Sampaio and Arroio Sampainho.
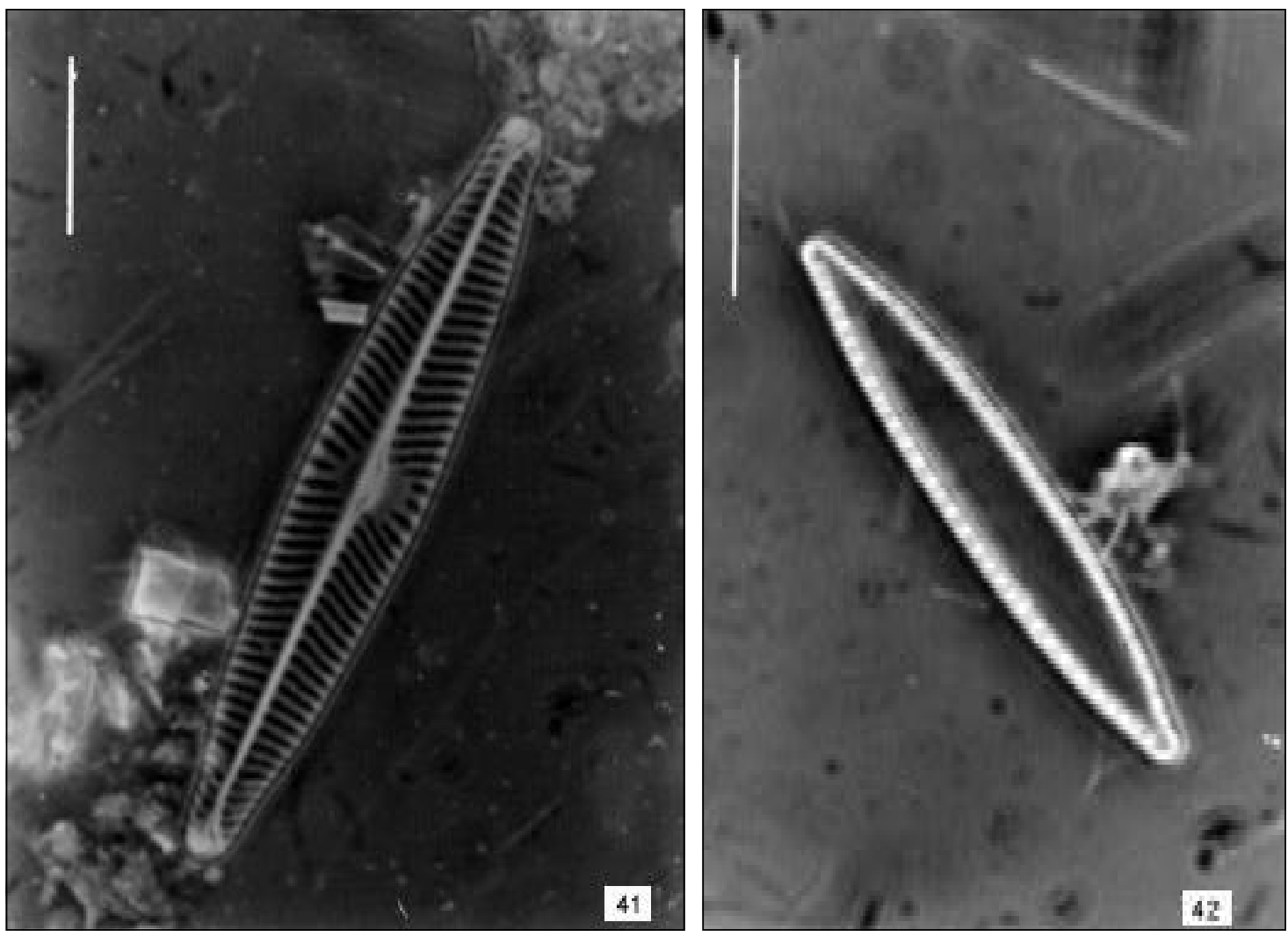

Figs. 41-42 - Association of representative species in the lower course of Arroio Teresinha. 41 - Navicula viridula. 42 Nitzschia palea. 


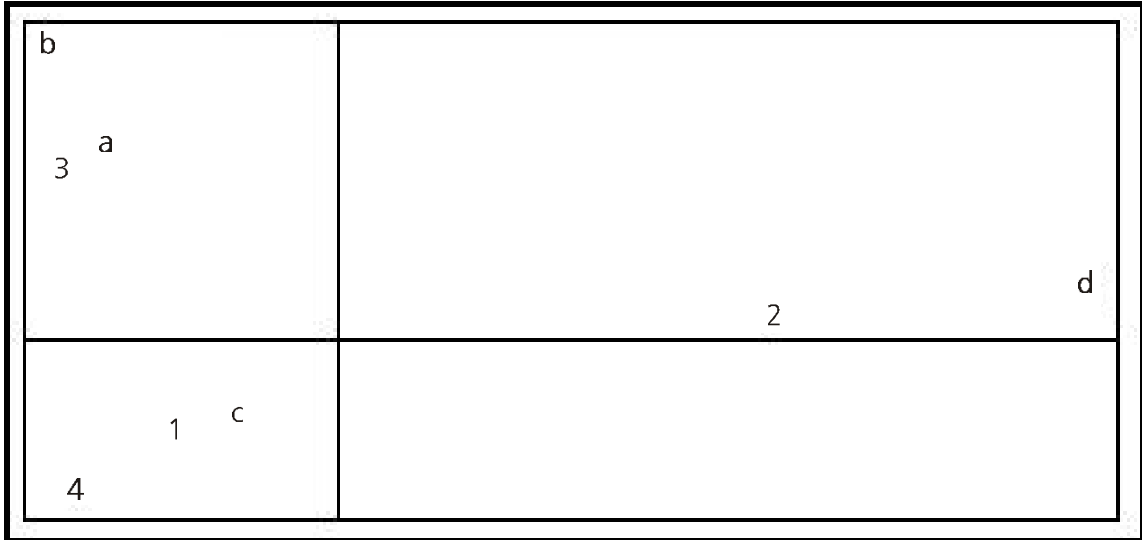

Fig. 43 - Analysis of concentration of the groupings of diatom species and sampling units.

The results of the physical and chemical analyses indicate that the sampling points distributed throughout the Arroio Sampaio basin generally presented a high time variability of the environmental structure (Table 1). However, the randomization test of the sampling unit groups showed that only group 4 was significantly different from the rest $(\mathrm{p}<0.05)$, while groups 1,2 , and 3 were part of the same data population.

Among the physical and chemical variables analyzed, phosphate was outstanding for presenting the highest values in group 4, as compared with the other groups, a trend clearly visible in Fig. 44.

TABLE 1

Descriptive statistics of the physical and chemical variables: Temperature (Temp.), $\mathrm{pH}(\mathrm{PH})$, Conductivity (Cond.), Turbidity (Turb), Dissolved Oxygen (DO), Biochemical Oxygen Demand $\left(\mathrm{BOD}_{5}\right)$, Nitrates $\left(\mathrm{NO}_{3}\right)$, Nitrites $\left(\mathrm{NO}_{2}\right)$, Phosphates $\left(\mathrm{PO}_{4}\right)$, and Total Solids (TS). [n= 75, $\mathrm{X}=$ mean, $\mathrm{S}=$ standard deviation, $\mathrm{VC}=$ variation coefficient, $V \min =$ minimum value, $\operatorname{Vmax}=\operatorname{maximum}$ value.]

\begin{tabular}{|c|c|c|c|c|c|c|c|c|c|c|}
\hline & $\begin{array}{c}\text { Temp. } \\
\left({ }^{\circ} \mathbf{C}\right)\end{array}$ & $\mathbf{p H}$ & $\begin{array}{c}\text { Cond. } \\
\left(\mathbf{u S} / \mathbf{c m}^{-1}\right)\end{array}$ & $\begin{array}{c}\text { Turb. } \\
\mathbf{( N T U )}\end{array}$ & $\begin{array}{c}\text { OD } \\
(\mathbf{m g} / \mathbf{L})\end{array}$ & $\begin{array}{c}\mathbf{B O D}_{5} \\
(\mathbf{m g} / \mathbf{L})\end{array}$ & $\begin{array}{c}\mathbf{N O}_{3} \\
(\mathbf{m g} / \mathbf{L})\end{array}$ & $\begin{array}{c}\mathbf{N O}_{2} \\
(\mathbf{m g} / \mathbf{L})\end{array}$ & $\begin{array}{c}\mathbf{P O}_{4} \\
(\mathbf{m g} / \mathbf{L})\end{array}$ & $\begin{array}{c}\text { TS } \\
(\mathbf{m g} / \mathbf{L})\end{array}$ \\
\hline $\mathrm{X}$ & 18.80 & 7.31 & 0.09 & 52.96 & 9.49 & 9.69 & 0.82 & 0.04 & 0.43 & 416.74 \\
\hline $\mathrm{S}$ & 4.79 & 0.31 & 0.04 & 123.70 & 1.41 & 6.09 & 0.76 & 0.04 & 0.37 & 658.22 \\
\hline $\mathrm{VC}$. & $25.50 \%$ & $4.24 \%$ & $44.40 \%$ & $233.57 \%$ & $14.80 \%$ & $62.80 \%$ & $92.70 \%$ & $100 \%$ & $86 \%$ & $157.95 \%$ \\
\hline Vmin & 10.90 & 6.60 & 0.03 & 2.00 & 5.58 & 2.40 & 0.06 & 0.00 & 0.00 & 14.00 \\
\hline Vmax & 29.20 & 8.51 & 0.24 & 661 & 12.85 & 35.48 & 4.01 & 0.18 & 1.34 & 4097 \\
\hline
\end{tabular}

However, when the Mann-Whitney U test was applied, no significant differences were observed $(p<0.05)$ between the groups. Even so, this finding does not detract from the fact that the highest phosphate values were observed in group 4 , since the highest values of the calculated standard deviation $(0.547 \pm 0.559 ; \mathrm{VC}=102.2 \%)$ directly influenced the non-rejection of the null hypothesis of the test. According to Gilbert (1989), this situation is one of the great disadvantages of the non-parametric statistical tests.

All phosphate values in the study, however, are above the maximum content for Class 3 of CONAMA, $0.077 \mathrm{mg} / \mathrm{L}$ (Fig. 44). According to these results, therefore, the waters of Arroio Sampaio and its tributaries could fit with class 4 of 
CONAMA, waters only for navigation, landscape harmony, and less demanding uses. These results indicate that the waters of the systems that are the subject of the present study have been undergoing a eutrophication process, which reached its high point at the sampling stations of group 4, confirming the high phosphate concentrations detected in these systems by Lobo \& Kirst (1997).

As regards the structure of the diatom biocenosis, the association of the species identified along Arroio Sampaio and its tributaries showed that this system was spatially heterogeneous, with four distinct species groups. According to the dispersion diagram, group c corresponded significantly to sampling unit groups 1 and 4, and group d to group 2 . Even considering this differentiation, the representative species of these groups fit into differential groups $\mathrm{B}$ and $\mathrm{AB}$ of the saprobe system proposed by Lobo et al. (1998), characterizing $\alpha$-mesosaprobiotic and $\alpha$-polysaprobiotic conditions of pollution, respectively. Differential group b includes Cocconeis placentula var. euglypta, representing species group c, whereas in differential group ab are classified taxa Gomphonema parvulum and Navicula symmetrica, representing species group c, and taxa Navicula aikenensis and Navicula viridula, representing species group $\mathrm{d}$. The diatom species belonging to differential groups $b$ and $a b$ are characteristic of waters whose $\mathrm{BOD}_{5}$ range from 7 to $22 \mathrm{mg} / \mathrm{L}$, indicating heavily and very heavily polluted conditions, respectively. This classification coincides with the $\mathrm{BOD}_{5}$ means obtained for the four groups of sampling units in this study, which were between 9.2 and $10.5 \mathrm{mg} / \mathrm{L}$ (Fig. 44). This range for $\mathrm{BOD}_{5}$ corresponds to class III ( $\alpha$-mesosaprobiotic) of the chemical classification proposed by Hamm (1969), characterizing strongly polluted waters.

It should be stressed, however, that most representative species are classified in differential group $\mathrm{AB}$, which characterizes $\alpha$-polysaprobiotic levels of pollution, with a $\mathrm{BOD}_{5}$, fluctuating from 13 to $22 \mathrm{mg} / \mathrm{L}$.

This difference could be explained by taking into account that the above mentioned saprobe system was developed to assess organic pollution in water, based on $\mathrm{BOD}_{5}$, and not taking into account the effects of eutrophication on the biological composition of the biocenosis. In fact, as shown in Fig. 45, at all sampling points the total phosphate concentration values were above the maximum content for class 3 of CONAMA, characterizing a eutrophication process.

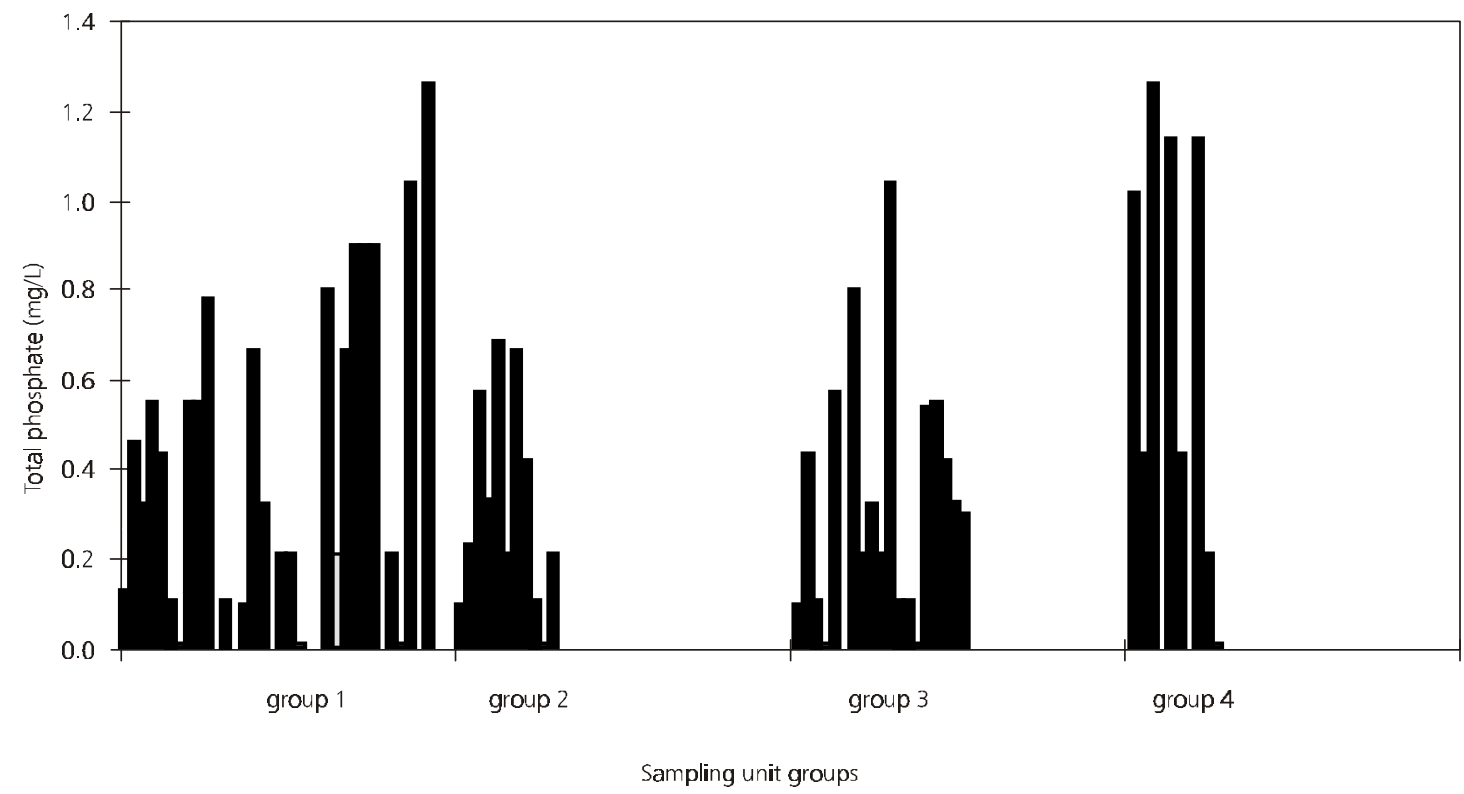

Fig. 44 - Total phosphate values for the 4 groups of sampling units in the basin of Arroio Sampaio, from July 1994 to June 1995 (in $\mathrm{mg} / \mathrm{L}$ ). 


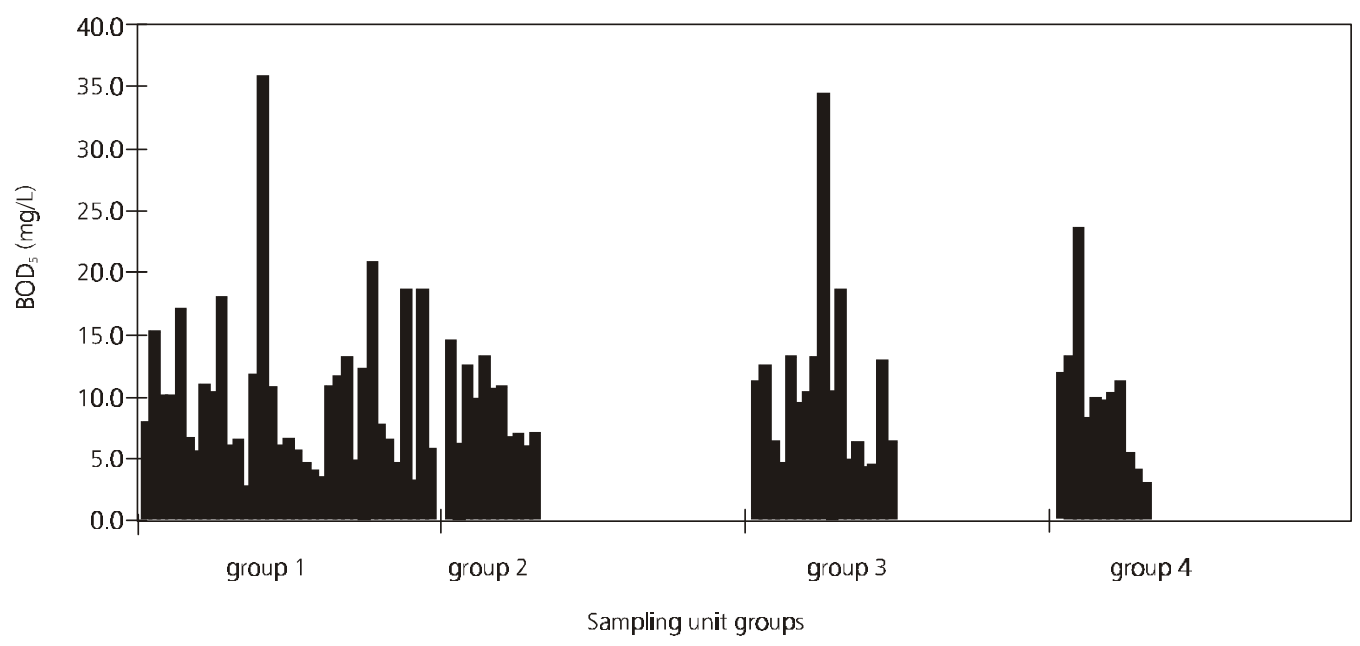

Fig. 45 - Biochemical oxygen demand values for the 4 groups of sampling units in the basin of Arroio Sampaio, from July 1994 to June 1995 (in $\mathrm{mg} / \mathrm{L}$ ).

These results confirm the hypothesis proposed by Lobo \& Kirst (1998), in which the response of the diatom biocenosis to water pollution in lotic systems in Southern Brazil is due to the interaction of variables which characterize a process of organic contamination and also eutrophication. Although the general trend of the basin studied is toward high levels of organic pollution and eutrophication, stations 4 and 7 (predominant in group 4 of the sampling units) presented this trend in a more marked form, particularly as regards the phenomenon of eutrophication. Lobo \& Kirst (1997) confirmed this trend when they worked in the Arroio Sampaio basin in the period from July 1996 to July 1997.

The results of this study indicated the occurrence of four associations of diatom species identified along Arroio Sampaio and its tributaries. Among the physical and chemical variables measured, water pollution, particularly organic contamination and eutrophication, determined from $\mathrm{BOD}_{5}$, and the concentration of total phosphate, respectively, were the most important environmental factors determining the composition and structure of the species associations in the study area.
Acknowledgments - We thank the Fundação de Amparo à Pesquisa do Rio Grande do Sul (FAPERGS), for awarding a scholarship to recent M.Sc. graduates, file nr.97/60014-3; our thanks to Professor Dr. Valério Pillar of the Federal University of Rio Grande do Sul and to biologist Maria Carmen Sestren Bastos, MSc, for advice and the use of the MULTIV and SYNCSA programs; to the technicians of the Laboratório de Análises de Águas da Universidade de Santa Cruz do Sul for the physical and chemical tests on water and for support in field work; and to technician Gilberto Machado of the Fundação Zoobotânica do Rio Grande do Sul for help in preparing the permanent slides.

\section{REFERENCES}

AMERICAN PUBLIC HEALTH ASSOCIATION (APHA), 1992, Standard Methods for the Examination of Water and Wastewater. APHA, Washington, DC20005, 18.ed. 905p.

CONAMA, 1990, Resoluções do CONAMA: 1984 a 1990. Conselho Nacional do Meio Ambiente, Brasil.

DIGBY, P. G. N. \& KEMPTON, R. A., 1987, Multivariate Analysis of Ecological Communities. Chapman and Hall, London and New York, 206p.

FERMINO-PAGANOTO, F. S., 1997, Estrutura e dinâmica de algas do perifiton de Eichornia azurea $(S w$.) Künth em lagoas costeiras eutrofizadas do litoral do Rio Grande do Sul (Osório, RS). Dissertação de Mestrado, Universidade Federal do Rio Grande do Sul, Porto Alegre. 127p. 
GILBERT, N., 1989, Biometrical interpretation. Making sense of statistics in biology. Oxford University Press, New York, 146p.

GOUGH, S. B. \& WOELKERLING, W. J., 1976, On the removal and quantification of algal aufwuchs from macrophyte hosts. Hydrobiol., 48(3): 203-207.

HAMM, A., 1969, Die Ermittlung der Gewässerguteklassen bei Fliessgewässern nach dem Gewassergutesystem und gewässerguttenomogramm. Müncher Beitrage zur Abwasser-Fischerei - und Flussbiologie, 15: 46-48.

LOBO, E. A. \& BUSELATO-TONIOLLI, T. C., 1985, Tempo de exposição de um substrato artificial para o estabelecimento da comunidade perifítica no curso inferior do Rio Caí, Rio Grande do Sul, Brasil. Rickia, 12: 35-51.

LOBO, E. A. et al., 1990, Distribuição vertical da estrutura da comunidade do perifíton sobre um substrato artificial no curso inferior do Rio Caí, Rio Grande do Sul, Brasil. Caderno de Pesquisa Sér. Bot., Santa Cruz do Sul, 2(1): 49-63.

LOBO, E. A., COSTA, A. B. \& OLIVEIRA, M. A., 1995, Estudo da qualidade da água do Arroio Boa Vista, município de Carlos Barbosa, Rio Grande do Sul, Brasil. Biociências, 3(1): 43-63.

LOBO, E. A., CALLEGARO, V. L. M., SCHÜLLER, S., OLIVEIRA, M. A., SALOMONI, S. \& ASAI, K., 1996, Pollution tolerant diatoms from rivers located in the Jacuí Basin, Rio Grande do Sul, Brazil. Iheringia Sér. Bot., 47: 43-70.

LOBO, E. A. \& BEN DA COSTA, A., 1997, Estudo da qualidade da água do Rio Pardinho, município de Santa Cruz do Sul, Rio Grande do Sul, Brasil. Revista TecnoLógica, 1(1): 11-36.

LOBO, E. A. \& KIRST, A., 1997, Estudo da qualidade da água dos arroios Sampaio, Grande e Bonito, e dos solos das lavouras circunvizinhas, no município de Mato Leitão, Rio Grande do Sul, Brasil. Relatório final, Universidade de Santa Cruz do Sul, Santa Cruz do Sul, 49p.

LOBO, E. A. \& BENDER, E. P., 1998, Aplicabilidade de sistemas de sapróbios para avaliação da qualidade de águas correntes fortemente poluídas no sul do Brasil, utilizando diatomáceas. Anais do IV Congresso Latino Americano de Ficologia, 1996. Minas Gerais, Brasil, 1: 401-422.

LOBO, E. A. \& KIRST, A., 1998, Estudo da qualidade da água dos arroios Areia, Boa Vista, Estrela, Glória e Rio Taquari, Município de Estrela, RS, Brasil. Relatório final, Universidade de Santa Cruz do Sul, Santa Cruz do Sul, $72 \mathrm{p}$.
LOBO, E. A., CALLEGARO, V. L. M., BENDER, E. P. \& ASAI, K., 1998, Guia Ilustrado para a Identificação de Diatomáceas Epilíticas Indicadoras da Qualidade da Água de Rios e Arroios da Bacia do Rio Jacuí, RS, Brasil. Relatório final, Universidade de Santa Cruz do Sul, Santa Cruz do Sul, 80p.

MÜLLER-MELCHERS, F. C. \& FERRANDO, H. J., 1956 Técnica para el estudio de las diatomeas. Bol. Inst. Ocean., São Paulo, 7(1-2): 151-60.

OLIVEIRA, M. A., 1996, Ecologia do perifiton de susbstrato artificial em cursos d'água do trecho médio do Arroio Sampaio, Mato Leitão, RS, Brasil. Dissertação de Mestrado, Universidade Federal do Rio Grande do Sul, Porto Alegre, 128p.

PIELOU, E. C., 1984, The Interpretarion of Ecological Data. John Willey and Sons, New York, 263p.

PILLAR, V. de P., 1995a, MULTIV. Aplicativo para análise exploratória multivariada e testes de hipóteses via aleatorização. Depto. Botânica, UFRGS, Porto Alegre (software).

PILLAR, V. de P., 1995b, SYNCSA. Aplicativo para análise exploratória multivariada e testes de hipóteses via aleatorização. Depto. Botânica, UFRGS, Porto Alegre (software).

ROUND, F. E., CRAWFORD, R. M. \& MANN, D. G., 1990, The Diatoms Biology and Morphology of the Genera. Cambridge Univ. Press, London, 747p

SCHWARZBOLD, A., 1992, Efeitos do regime de inundação do rio Mogi-Guaçu (SP) sobre a estrutura, diversidade, produção e estoques do perifíton de Eichornia azurea (Sw) Kunth da Lagoa do Infernão. Tese de Doutorado, Universidade Federal de São Carlos, São Carlos, 237p.

SIEGEL, S., 1956, Estatística Não-Paramétrica para as ciências do comportamento. McGraw-Hill do Brasil, São Paulo, v. 1, 350p.

TEDESCO, C., 1995, Variação espacial e sazonal de microalgas perifíticas em substrato artificial na margem nordeste da Lagoa Caconde, Osório, Rio Grande do Sul. Dissertação de Mestrado, Universidade Federal do Rio Grande do Sul, Porto Alegre, 88p.

UTERMÖHL, H., 1958, Zur vervollkommung der quantitativen phytolankton-methodik. Mitt. d. Internat. Vereinig. f. Limnologie, 9: 1-39.

WETZEL, R. G. \& LIKENS, E., 1990, Limnological Analysis. Springer-Verlag, London, 391p. 